\title{
Thermal degradation of the anthocyanins extracts from jabuticaba peels and red cabbage leaves
}

Degradação térmica de extratos antociânicos das cascas de jabuticaba e das folhas de repolho roxo

\author{
P. P. Souza; W. S. Robazza; A. C. Galvão* \\ Department of Food and Chemical Engineering, Laboratory ApTher-Applied Thermophysics, Santa Catarina State \\ University - UDESC, 89870-000, Pinhalzinho-SC, Brazil \\ *alessandro.galvao@udesc.br
}

(Recebido em 30 de março de 2020; aceito em 09 de junho de 2020)

\begin{abstract}
Anthocyanins are phenolic compounds with tinctorial capacity. Their successful extraction and purification depends on information associated with their thermal stability. This work presents a study on the degradation kinetics of the anthocyanins in the peels of the jabuticaba fruits and the leaves of red cabbage through assays performed at different temperatures (ranging from $323.15 \mathrm{~K}$ to $363.15 \mathrm{~K}$ ) and degradation times (up to 10 hours for jabuticaba and 30 hours for red cabbage). Total monomeric anthocyanins were determined through the $\mathrm{pH}$ differential method. Regarding the extraction, it was observed a larger quantity of anthocyanins from red cabbage extracts, with an average value of $1.3774 \mathrm{mg} \cdot \mathrm{g}_{\mathrm{db}}{ }^{-1}$, when compared to jabuticaba extracts, with an average value of $1.0479 \mathrm{mg} \cdot \mathrm{g}_{\mathrm{db}}{ }^{-1}$. The results suggest that the anthocyanins in the red cabbage leaves are much more thermally stable than the anthocyanins in the jabuticaba peels. The experimental assays suggest that the thermal degradation reaction proceeds according to a first-order kinetics model for the anthocyanins in both sources under study. The experimental values were treated according to their thermodynamic relations, which indicated that the thermal degradation process of the evaluated anthocyanins is endothermic and not spontaneous, with similar values of $64.8 \mathrm{~kJ} \cdot \mathrm{mol}^{-1}$ for the red cabbage and $70.2 \mathrm{~kJ} \cdot \mathrm{mol}^{-1}$ for the jabuticaba.
\end{abstract}

Keywords: Brassica oleraceae, Myrciaria cauliflora, kinetics.

Antocianinas são compostos fenólicos que apresentam capacidade tintorial. Sua extração e purificação bemsucedidas dependem de informações associadas à sua estabilidade térmica. Este trabalho apresenta um estudo da cinética de degradação das antocianinas presentes nas cascas da jabuticaba e nas folhas do repolho roxo com ensaios realizados a diferentes temperaturas (entre $323.15 \mathrm{~K}$ e $363.15 \mathrm{~K}$ ) e tempos de degradação (até 10 horas para a jabuticaba e 30 horas para o repolho roxo). As antocianinas monoméricas totais foram determinadas pelo método de $\mathrm{pH}$ diferencial. Em relação a extração, foi observada uma maior quantidade de antocianinas no extrato de repolho roxo, com um valor médio de $1.3774 \mathrm{mg} \cdot \mathrm{g}_{\mathrm{db}}{ }^{-1}$, quando comparado ao extrato de jabuticaba, com um valor médio de $1.0479 \mathrm{mg} \cdot \mathrm{g}_{\mathrm{db}}{ }^{-1}$. Os resultados indicaram que as antocianinas presentes nas folhas do repolho roxo são muito mais estáveis termicamente do que as antocianinas presentes nas cascas da jabuticaba. Os ensaios experimentais indicaram que a reação de degradação térmica segue uma cinética de primeira ordem para as antocianinas presentes em ambas as fontes estudadas. Os valores experimentais foram tratados por relações termodinâmicas que indicaram que o processo de degradação térmica das antocianinas avaliadas é endotérmico e não espontâneo, com valores similares de $64.8 \mathrm{~kJ} \cdot \mathrm{mol}^{-1}$ para o repolho roxo e $70.2 \mathrm{~kJ} \cdot \mathrm{mol}^{-1}$ para a jabuticaba.

Palavras chave: Brassica oleraceae, Myrciaria cauliflora, cinética.

\section{INTRODUCTION}

The quality of food products and their visual appeal are directly related to color [1]. According to literature [2], color stands out as one of the most important sensory attributes of a food item. It is therefore assumed that the quality and quantity of pigments in a food product are essential for its commercial acceptance [3].

Although synthetic colorants have a lower cost of production, greater stability and greater tinctorial capacity, one aspect that should be strongly considered is the fact that every passing year the number of permitted synthetic additives for use in the food industry decreases [4]. The use of artificial colorants has been questioned by different segments of society, and together with the continuous negative publicity, this trend has increased the interest in colorants of natural origin. 
The replacement of synthetic colorants by natural colorants has therefore been strongly advocated by consumers who seek products with positive effects on human health.

Anthocyanins stand out among the natural colorants. They make up the largest group of watersoluble pigments of the vegetable kingdom [5] and are part of the flavonoid class. These biocompounds with antioxidant properties are attracting great interest in the food, pharmaceutical and cosmetic industry mainly because of their presence in many fruits and vegetables [6] and their antioxidant [7], anticarcinogenic [8, 9] and antiviral capacity [9].

Unfortunately, the extraction/purification of the pigment and its successful incorporation into food items is still in need of further studies, especially concerning the degradation kinetics of these pigments when they are subjected to light, temperature fluctuations and $\mathrm{pH}$, among other factors [10].

The red cabbage (Brassica oleracea L.), a rich source of anthocyanins [11], has its consumption associated with the prevention of diseases [12]. The vegetable is characterized by its long shelf life and therefore, can be easily stored [13]. The use of organic solvents associated with the extraction capability and the stability of the extracts is a subject of importance [14].

The jabuticaba (Myrciaria cauliflora Mart.) is known as one of the richest sources of anthocyanins in Brazil [15]. Due to the content of sugar, organic acid and terpene, the fruit has a sweet and sub-acidic flavor [16]. Balisteiro et al. (2017) [17] and Hsu et al. (2016) [18] suggest that its extract may be used as an alternative for the treatment of hyperglycemia.

The application of mathematical models capable of interpreting the kinetic parameters of the thermal degradation of anthocyanins, such as the reaction order, reaction rate, activation energy, enthalpy, entropy and Gibbs energy, has become essential to predict the quality losses that can occur during the thermal processing of products containing anthocyanins [19, 20].

In line with the importance of developing studies related to the degradation of anthocyanins, this work seeks to extract anthocyanins from jabuticaba peels (M. cauliflora) and red cabbage leaves (B. oleraceae) using water as a solvent and subjecting the anthocyanin extracts to different temperatures as a function of time to evaluate their thermal degradation. The experimental results were submitted to models to determine the kinetic and thermodynamic degradation parameters.

\section{METHODOLOGY}

The jabuticabas and red cabbages were carefully cleaned with tap water and the parts in the fruits and vegetables rich in anthocyanin (jabuticaba peels and red cabbage leaves) compounds were separated. Subsequently, the materials were dried in an oven with air circulation for a period of 48 hours at a temperature of $313.15 \mathrm{~K}$. After drying, the materials were ground in a food processor and separated into particles smaller than $0.833 \mathrm{~mm}$ using a 20 -mesh sieve. The samples were then placed in portions of 5 grams in a sealed package and kept in an ULT freezer at $188 \mathrm{~K}$ until the performance of the extraction.

The extraction was carried out with a jacketed glass cell connected to a thermostatic bath. A ratio of $60 \mathrm{ml}$ of solvent (distilled water) per gram of dry material was used. The extraction was performed for a period of $3 \mathrm{~h}$ at a temperature of $313.15 \mathrm{~K}$. The mixture was submitted to stirring at a controlled temperature to complete the mass transfer. After filtering the solution, the anthocyanin extract was put in $4.5 \mathrm{ml}$ amber polypropylene tubes and then submitted to thermal degradation.

The red cabbage extracts were subjected to degradation for $30 \mathrm{~h}$, with an evaluation in duplicate each $10 \mathrm{~h}$ (including $t=0$ ) at four temperatures distributed in the interval between 323.15 and $353.15 \mathrm{~K}$. The jabuticaba peel extracts were subjected to degradation for $10 \mathrm{~h}$, with an evaluation in duplicate every $2 \mathrm{~h}$ (including $t=0$ ) at five temperatures distributed in the interval between 323.15 and $363.15 \mathrm{~K}$. Total monomeric anthocyanins (TMA) were determined using the $\mathrm{pH}$ differential method [21].

The $\mathrm{pH}$ differential method is based on the structural transformation of the anthocyanin as a function of $\mathrm{pH}$ in two buffer solutions: potassium chloride with $\mathrm{pH} 1.0(0.025 \mathrm{M})$ and sodium acetate with pH $4.5(0.4 \mathrm{M})$. According to this method, the difference in absorbance of the solutions of $\mathrm{pH} 1.0$ and 4.5 is directly proportional to the concentration of TMA. After dilution of the extract, aliquots containing anthocyanins are buffered and the absorbance of the samples is determined at 
the wavelengths of $510 \mathrm{~nm}$ and $700 \mathrm{~nm}$. Total monomeric anthocyanins are calculated on a dry base $\left(\mathrm{mg} \cdot \mathrm{g}_{\mathrm{db}}{ }^{-1}\right)$ with reference to cyanidin-3-glucoside, as represented by Equation (1).

$\mathrm{TMA}=\frac{\left(\left[\left(A_{510}-A_{700}\right)_{p H 1.0}-\left(A_{510}-A_{700}\right)_{p H 4.5}\right] \cdot M W \cdot V \cdot \mathrm{DF} \cdot 1000\right)}{(\varepsilon \cdot m \cdot 1)}$

In equation (1), $M W$ represents the molar mass of cyanidin-3-glucoside ( 449.2 g.mol $\left.^{-1}\right)$, DF is the dilution factor of the sample, $\varepsilon$ is the molar extinction coefficient of cyanidin-3-glucoside (26.9 L. $\left.\mathrm{mol}^{-1} \cdot \mathrm{cm}^{-1}\right), 1000$ represents the conversion of $\mathrm{g}$ to $\mathrm{mg}, 1$ is the path of the wave in the cuvette in $\mathrm{cm}, V$ is the volume of the extracted solution and $m$ is the dry solid mass used in the extraction. The determinations were performed using a digital scanning UV/VIS spectrophotometer of the brand Fento, model Cirrus 80SA.

The experimental uncertainty of total monomeric anthocyanins ( $\delta \mathrm{TMA})$ was estimated by a propagation method [22]. It was assumed that the final uncertainty depends on each uncertainty of absorbance $(\delta A)$ for both $\mathrm{pHs}$ and wavelengths, mass $(\delta m)$, volume $(\delta V)$ and partial derivatives of Equation 1 as a function of all dependent variables. In accordance with the method the calculation takes the form presented by Equation (2).

$$
\begin{gathered}
\delta \mathrm{TMA}=\left(\left(\frac{\partial \mathrm{TMA}}{\partial A_{p H 1.0}^{510}}\right)^{2}\left(\delta A_{p H 1.0}^{510}\right)^{2}+\left(\frac{\partial \mathrm{TMA}}{\partial A_{p H 1.0}^{700}}\right)^{2}\left(\delta A_{p H 1.0}^{700}\right)^{2}+\left(\frac{\partial \mathrm{TMA}}{\partial A_{p H 4.5}^{510}}\right)^{2}\left(\delta A_{p H 4.5}^{510}\right)^{2}\right. \\
\left.+\left(\frac{\partial \mathrm{TMA}}{\partial A_{p H 4.5}^{700}}\right)^{2}\left(\delta A_{p H 4.5}^{700}\right)^{2}+\left(\frac{\partial \mathrm{TMA}}{\partial m}\right)^{2}(\delta m)^{2}+\left(\frac{\partial \mathrm{TMA}}{\partial V}\right)^{2}(\delta V)^{2}\right)^{\frac{1}{2}}
\end{gathered}
$$

Previous studies conducted in different food matrices [23-26] suggest that the thermal degradation kinetics of anthocyanins proceed as a first-order reaction, as shown by Equation (3). The concentration of anthocyanins $C_{t}$ determined at a constant temperature after a degradation time $t$ from a known initial concentration $C_{0}$ enables the determination of the reaction kinetics constant $k$. Knowing the kinetics constant of the reaction determines the half-life time according to Equation (4).

$C_{t}=C_{0} \cdot \exp (-k \cdot t)$

$t_{1 / 2}=-\frac{\ln 0.5}{k}$

The dependence of the thermal degradation of the anthocyanins with temperature can be represented by the Arrhenius equation, Equation (5), where $k_{0}$ is defined as a frequency factor, $E_{a}$ is the activation energy, $R$ is the universal gas constant and $T$ is the assay temperature. To determine the effect of temperature on the desired kinetic parameters, the constants obtained in Equation (3) are linearized by plotting $k$ as a function of the inverse of the temperature, making it possible to relate the frequency factor with the linear coefficient of the curve and the activation energy $\left(E_{a}\right)$ with the angular coefficient of the curve.

$k=k_{0} \cdot \mathrm{e}^{-\frac{E_{a}}{R T}}$

In addition to the activation energy, such quantities as the Gibbs energy of activation $\Delta G^{\ddagger}$, the activation enthalpy $\Delta H^{\ddagger}$ and the activation entropy $\Delta S^{\ddagger}$ provide important information about the molecular interactions during the thermal degradation. These quantities can be determined with the Eyring-Polanyi model [27-31] based on the transition-state theory and expressed by Equation (6).

$k=\frac{k_{B}}{h} \cdot T \cdot \mathrm{e}^{-\frac{\Delta G^{\ddagger}}{R T}}$ 
In Equation (6), $k_{B}$ is the Boltzmann constant $\left(1.38064852 \times 10^{-23} \mathrm{~J} \cdot \mathrm{K}^{-1}\right)$ and $h$ represents the Planck's constant $\left(6.626070040 \times 10^{-34} \mathrm{~J} \cdot \mathrm{s}\right)$. The Gibbs energy of activation is defined by the thermodynamic relationship presented by Equation (7), where, for a first-order reaction, the activation enthalpy can be determined as suggested in Equation (8).

$\Delta G^{\ddagger}=\Delta H^{\ddagger}-T \cdot \Delta S^{\ddagger}$

$\Delta H^{\ddagger}=E_{a}-R \cdot T$

All statistical analyses were conducted with Microsoft Excel 2013. Results were expressed as means \pm experimental uncertainty. The effects of time and temperature on concentration of TMA were determined by one-way ANOVA. The significant difference between means was evaluated by Tukey's post hoc test. The level of significance of all testes was 0.05 .

\section{RESULTS AND DISCUSSION}

Tables 1 and 2 show the experimental concentrations of total monomeric anthocyanins in the red cabbage leaves and jabuticaba peels in dry solid base as a function of time and degradation temperature along with experimental uncertainties of TMA. Figure 1 shows the degradation profiles and Figure 2 shows the behavior of the first-order model. In general, as can be seen from Tables 1 and 2, the concentration of TMA statistically decreased with time at all studied temperatures. Moreover, the experimental behavior of TMA from red cabbage was sharper in relation to jabuticaba peels as the differences between means were observed at most of the evaluated data points. In what concerns the jabuticaba peels, the differences were more pronounced after $8 \mathrm{~h}$ of storage.

Table 1: Concentration of total monomeric anthocyanins (TMA) expressed as $m \cdot g_{d b}{ }^{-1}$ in red cabbage leaves as a function of temperature and degradation time ( $t$ ) along with experimental uncertainty.

\begin{tabular}{ccccc}
\hline $\boldsymbol{t}$ (h) & TMA & TMA & TMA & TMA \\
& $\mathbf{3 2 3 . 1 5} \mathbf{~ K}$ & $\mathbf{3 3 3 . 1 5} \mathbf{K}$ & $\mathbf{3 4 3 . 1 5} \mathbf{~ K}$ & $\mathbf{3 5 3 . 1 5} \mathbf{~ K}$ \\
\hline 0 & $1.394 \pm 0.011^{\mathrm{aA}}$ & $1.445 \pm 0.012^{\mathrm{aA}}$ & $1.349 \pm 0.012^{\mathrm{aA}}$ & $1.321 \pm 0.011^{\mathrm{aA}}$ \\
10 & $1.244 \pm 0.010^{\mathrm{bA}}$ & $1.145 \pm 0.012^{\mathrm{bB}}$ & $0.839 \pm 0.011^{\mathrm{bC}}$ & $0.701 \pm 0.012^{\mathrm{bD}}$ \\
20 & $1.166 \pm 0.010^{\mathrm{cA}}$ & $0.903 \pm 0.010^{\mathrm{cB}}$ & $0.584 \pm 0.011^{\mathrm{cC}}$ & $0.331 \pm 0.011^{\mathrm{cD}}$ \\
30 & $1.086 \pm 0.011^{\mathrm{dA}}$ & $0.629 \pm 0.011^{\mathrm{dB}}$ & $0.410 \pm 0.010^{\mathrm{dC}}$ & $0.168 \pm 0.010^{\mathrm{cD}}$ \\
\hline
\end{tabular}

Means with different small letters in the same column differ significantly $(\mathrm{p}<0.05)$. Means with different capital letters in the same row differ significantly $(\mathrm{p}<0.05)$.

Table 2: Concentration of total monomeric anthocyanins (TMA) expressed as $\mathrm{mg}^{\cdot} \mathrm{g}_{\mathrm{db}}{ }^{-1}$ in jabuticaba peels as a function of temperature and degradation time ( $t$ ) along with experimental uncertainty.

\begin{tabular}{cccccc}
\hline \multirow{2}{*}{$\boldsymbol{t h})$} & TMA & TMA & TMA & TMA & TMA \\
& $\mathbf{3 2 3 . 1 5} \mathbf{~ K}$ & $\mathbf{3 3 3 . 1 5} \mathbf{~ K}$ & $\mathbf{3 4 3 . 1 5} \mathbf{~ K}$ & $\mathbf{3 5 3 . 1 5} \mathbf{~ K}$ & $\mathbf{3 6 3 . 1 5} \mathbf{~ K}$ \\
\hline 0 & $0.984 \pm 0.010^{\mathrm{bA}}$ & $1.052 \pm 0.010^{\mathrm{dA}}$ & $1.024 \pm 0.011^{\mathrm{dA}}$ & $1.171 \pm 0.012^{\mathrm{eB}}$ & $1.008 \pm 0.011^{\mathrm{eA}}$ \\
2 & $0.953 \pm 0.011^{\mathrm{abA}}$ & $0.949 \pm 0.012^{\mathrm{aA}}$ & $0.792 \pm 0.010^{\mathrm{aB}}$ & $0.755 \pm 0.011^{\mathrm{aB}}$ & $0.640 \pm 0.010^{\mathrm{aC}}$ \\
4 & $0.933 \pm 0.011^{\mathrm{abcA}}$ & $0.901 \pm 0.010^{\mathrm{aA}}$ & $0.745 \pm 0.012^{\mathrm{aB}}$ & $0.645 \pm 0.010^{\mathrm{bC}}$ & $0.313 \pm 0.011^{\mathrm{bD}}$ \\
6 & $0.904 \pm 0.010^{\mathrm{addE}}$ & $0.803 \pm 0.010^{\mathrm{bA}}$ & $0.636 \pm 0.010^{\mathrm{bB}}$ & $0.439 \pm 0.010^{\mathrm{cC}}$ & $0.152 \pm 0.010^{\mathrm{cD}}$ \\
8 & $0.873 \pm 0.010^{\mathrm{cdE}}$ & $0.782 \pm 0.011^{\mathrm{bA}}$ & $0.557 \pm 0.011^{\mathrm{cB}}$ & $0.372 \pm 0.010^{\mathrm{cdC}}$ & $0.089 \pm 0.011^{\mathrm{cdD}}$ \\
10 & $0.853 \pm 0.011^{\mathrm{dE}}$ & $0.625 \pm 0.010^{\mathrm{cA}}$ & $0.511 \pm 0.010^{\mathrm{cB}}$ & $0.303 \pm 0.011^{\mathrm{dC}}$ & $0.046 \pm 0.011^{\mathrm{dD}}$ \\
\hline
\end{tabular}

Means with different small letters in the same column differ significantly $(\mathrm{p}<0.05)$. Means with different capital letters in the same row differ significantly $(\mathrm{p}<0.05)$.

Regarding the extraction, it should be noted that the process used allows for the extraction of a larger quantity of anthocyanins from red cabbage, with an average value of $1.3774 \mathrm{mg} \cdot \mathrm{g}_{\mathrm{db}}{ }^{-1}$, when compared to jabuticaba, with an average value of $1.0479 \mathrm{mg} \cdot \mathrm{g}_{\mathrm{db}}{ }^{-1}$, representing an increase of $31 \%$ in the extraction capacity. The observed difference in the yields of extraction can be attributed to many aspects. It can be cited the different type of anthocyanin present in the material and its specific 
interaction with water. Moreover, the diffusion of water through the material depends on the characteristics of the plant tissue.

The results suggest that the anthocyanins in the red cabbage leaves, using water as solvent, are much more thermally stable than the anthocyanins in the jabuticaba peels. This finding is believed to be due to the effect of co-pigmentation that occurs in the red cabbage extracts [32]. For both evaluated materials, the study suggests a considerable stability until the temperature of $323.15 \mathrm{~K}$. At the temperature of $333.15 \mathrm{~K}$ there is a much greater influence of the temperature on degradation. Studies in the literature [33 - 35] also suggest a more pronounced instability of anthocyanins with temperatures exceeding $333.15 \mathrm{~K}$.
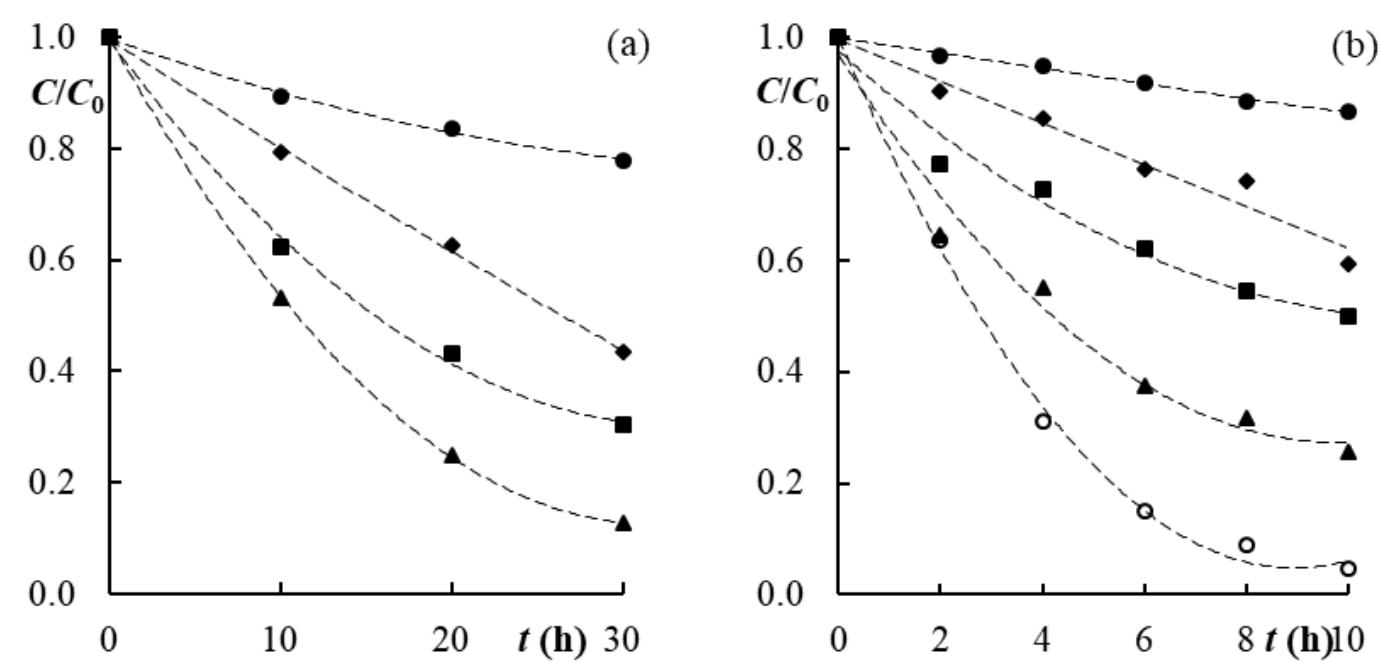

Figure 1: Degradation profile of anthocyanins in red cabbage (a) and jabuticaba (b): $\bullet 323.15 \mathrm{~K}, \boldsymbol{3 3 3 . 1 5}$ $K$, 『 $343.15 \mathrm{~K}, \boldsymbol{\Delta} 353.15 \mathrm{~K}$, ○ $363.15 \mathrm{~K}$.
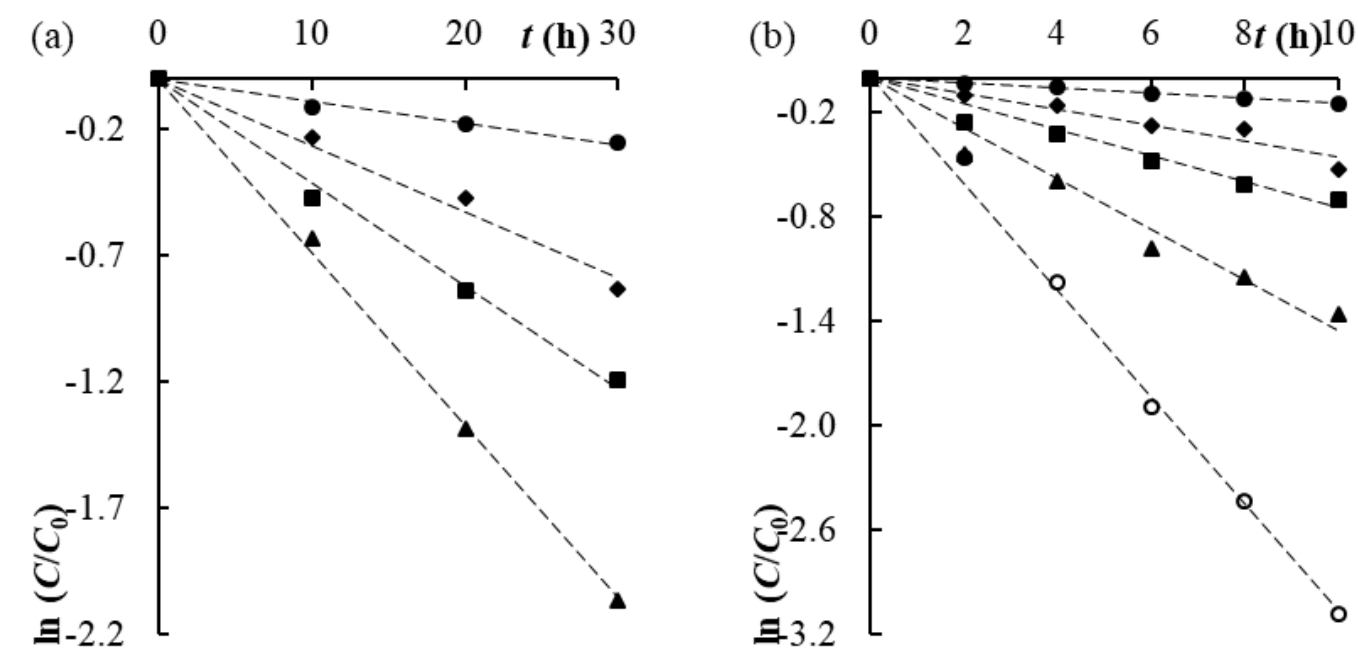

Figure 2: First-order model behavior for the degradation of the anthocyanins in red cabbage (a) and jabuticaba $(b): \bullet 323.15 \mathrm{~K}, \diamond 333.15 \mathrm{~K}, \mathbf{\square} 33.15 \mathrm{~K}, \boldsymbol{\Delta} 353.15 \mathrm{~K}, \circ 363.15 \mathrm{~K}$.

In the evaluated time and temperature intervals, the degradation of anthocyanins in the red cabbage leaves and jabuticaba peels satisfactorily follow a first-order reaction, given that the worst correlation coefficient in the adjustment of the model to the experimental data was 0.9817 and 0.9433 for the cabbage and jabuticaba, respectively. The results for the activation energy reveal similar values for the degradation of anthocyanins in the two materials under study, $64.8 \mathrm{~kJ} \cdot \mathrm{mol}^{-1}$ for the red cabbage and $70.2 \mathrm{~kJ} \cdot \mathrm{mol}^{-1}$ for the jabuticaba, following the same order of magnitude as previously published studies [36 - 38].

The kinetic degradation parameters for both the red cabbage leaves and jabuticaba peels at each temperature under study are presented in Table 3 . One can see that the values of the kinetic constant 
$k$ increase as the temperature increases, confirming the idea that the degradation of anthocyanins increases as the temperature increases. The $t_{1 / 2}$ values for the anthocyanins varied between 2.2 and $85.2 \mathrm{~h}$, where the higher values indicate a greater thermal stability of the anthocyanins present in the red cabbage leaves.

The thermodynamic activation quantities, also shown in Table 3, reveal similar values for the degradation of anthocyanins in both the red cabbage and jabuticaba. The positive values of $\Delta H^{\ddagger}$ are associated with the need for energy in the breaking of the bonds while the reagents reach the activated state in an endothermic and non-spontaneous transformation, as suggested by the positive values of $\Delta G^{\ddagger}$.

Table 3: Kinetic constant $(K)$, half-life time $\left(t_{1 / 2}\right)$, Gibbs energy of activation $\left(\Delta G^{\ddagger}\right)$, activation enthalpy $\left(\Delta H^{\ddagger}\right)$ and activation entropy $\left(T \cdot \Delta S^{\ddagger}\right)$ for the degradation at different temperatures $(T)$ of the anthocyanins in red cabbage leaves and jabuticaba leaves.

\begin{tabular}{|c|c|c|c|c|c|}
\hline$T(\mathbf{K})$ & $K\left(\mathbf{h}^{-1}\right)$ & $t_{1 / 2}(h)$ & $\Delta G^{\ddagger}\left(\mathrm{kJ} \cdot \mathrm{mol}^{-1}\right)$ & $\Delta H^{\ddagger}\left(\mathrm{kJ} \cdot \mathrm{mol}^{-1}\right)$ & $T \cdot \Delta S^{\ddagger}\left(\mathrm{kJ} \cdot \mathrm{mol}^{-1}\right)$ \\
\hline \multicolumn{6}{|c|}{ Red cabbage } \\
\hline 323.15 & 0.0081 & 85.2 & 114.29 & 62.13 & -52.16 \\
\hline 333.15 & 0.0273 & 25.3 & 114.56 & 62.05 & -52.51 \\
\hline 343.15 & 0.0394 & 17.6 & 117.04 & 61.97 & -55.07 \\
\hline 353.15 & 0.0694 & 10.0 & 118.87 & 61.88 & -56.98 \\
\hline \multicolumn{6}{|c|}{ Jabuticaba } \\
\hline 323.15 & 0.0145 & 47.9 & 112.75 & 67.59 & -45.16 \\
\hline 333.15 & 0.0472 & 14.7 & 113.05 & 67.50 & -45.54 \\
\hline 343.15 & 0.0669 & 10.4 & 115.52 & 67.42 & -48.10 \\
\hline 353.15 & 0.1327 & 5.2 & 116.97 & 67.34 & -49.63 \\
\hline 363.15 & 0.3150 & 2.2 & 117.75 & 67.25 & -50.50 \\
\hline
\end{tabular}

The activation entropy is associated with the number of molecules that have enough energy to react [39], negative values of $\Delta S^{\ddagger}$ indicate that the molecules have less structural freedom than the reagents in the transition state so that a larger amount of energy is required for the formation of the activated complex.

\section{CONCLUSION}

The thermal degradation study of the anthocyanins in the red cabbage leaves and jabuticaba peels was successfully correlated by a first-order model. When comparing the degradation of the anthocyanins in the red cabbage with the degradation of the anthocyanins in the jabuticaba peels, one can see that the anthocyanins in the cabbage are less susceptible to thermal degradation. The evaluation of kinetic parameters generated by the transition-state theory suggests that the degradation of anthocyanins in the two evaluated materials is endothermic and not spontaneous. The thermodynamic parameters can help to understand the nature of the thermal degradation of anthocyanin extract from the two investigated species.

\section{ACKNOWLEDGMENTS}

The authors would like to thank CAPES (Coordenação de Aperfeiçoamento de Pessoal de Nível Superior) and FAPESC (Fundação de Amparo à Pesquisa e Inovação do Estado de Santa Catarina, project number 2019RT583) for the financial support.

\section{REFERENCES}

1. Reyes LF, Cisneros-Zevallos L. Degradation kinetics and colour of anthocyanins in aqueous extracts of purple- and red-flesh potatoes (Solanum tuberosum L.). Food Chem. 2007 Jan;100(3):885-94, doi: 10.1016/j.foodchem.2005.11.002.

2. Sayar S, Özdemir Y. First-derivative spectrophotometric determination of ponceau 4R, sunset yellow and tartrazine in confectionery products. Food Chem. 1998 Mar;61(3):367-72. 
3. Morais H, Ramos C, Forgács E, Cserháti T, Oliviera J. Influence of storage conditions on the stability of monomeric anthocyanins studied by reversed-phase high-performance liquid chromatography. J Chromatogr B Analyt Technol Biomed Life Sci. 2002 Apr;770(1-2):297-301, doi: 10.1016/s15700232(02)00055-7

4. Francis FJ, Markakis PC. Food colorants: Anthocyanins. Crit Rev Food Sci Nutr. 1989 Jan;28(4):273314, doi: 10.1080/10408398909527503

5. Bridle P, Timberlake CF. Anthocyanins as natural food colours - selected aspects. Food Chem. 1997 Jan;58(1-2):103-9, doi: 10.1016/S0308-8146(96)00222-1.

6. Delgado-Vargas F, Jiménez AR, Paredes-López O. Natural Pigments: Carotenoids, Anthocyanins, and Betalains - Characteristics, Biosynthesis, Processing, and Stability. Crit Rev Food Sci Nutr. 2000 May;40(3):173-289. doi: 10.1080/10408690091189257

8. Hagiwara A, Miyashita K, Nakanishi T, Sano M, Tamano S, Kadota T, et al. Pronounced inhibition by a natural anthocyanin, purple corn color, of 2-amino-1-methyl-6-phenylimidazo[4,5-b]pyridine (PhIP)associated colorectal carcinogenesis in male F344 rats pretreated with 1,2-dimethylhydrazine. Cancer Lett. 2001 Aug;171(1):17-25, doi: 10.1016/s0304-3835(01)00510-9

9. Kapadia G. Inhibition of 12-O-tetradecanoylphorbol-13-acetate induced Epstein-Barr virus early antigen activation by natural colorants. Cancer Lett, 1997 May;115(2):173-8, doi: 10.1016/s03043835(97)04726-5

10. Skrede G, Wrolstad RE, Durst RW. Changes in Anthocyanins and Polyphenolics During Juice Processing of Highbush Blueberries (Vaccinium corymbosum L.). J Food Sci. 2000 Mar;65(2):357-64, doi: 10.1111/j.1365-2621.2000.tb16007.x

11. Mizgier P, Kucharska AZ, Sokół-Łętowska A, Kolniak-Ostek J, Kidoń M, Fecka I. Characterization of phenolic compounds and antioxidant and anti-inflammatory properties of red cabbage and purple carrot extracts. J Funct Foods. 2016 Mar;21:133-46, doi: 10.1016/j.jff.2015.12.004

12. Sarkar D, Rakshit A. Red cabbage as potential functional food in the present perspective. Int J Bioresour Sci. 2017;4(1):7, doi: 10.5958/2454-9541.2017.00002.0

13. Wiczkowski W, Szawara-Nowak D, Topolska J. Red cabbage anthocyanins: Profile, isolation, identification, and antioxidant activity. Food Res Int. 2013 Apr;51(1):303-9.

14. Hosseini S, Gharachorloo M, Ghiassi-Tarzi B, Ghavami M. Evaluation the Organic Acids Ability for Extraction of Anthocyanins and Phenolic Compounds from different sources and Their Degradation Kinetics during Cold Storage. Polish J Food Nutr Sci. 2016 Dec 31;66(4):261-9, doi: 10.1515/pjfns-20150057

15. Oliveira LC, Alencar NMM, Steel CJ. Improvement of sensorial and technological characteristics of extruded breakfast cereals enriched with whole grain wheat flour and jabuticaba (Myrciaria cauliflora) peel. LWT. 2018 Apr;90:207-14, doi: 10.1016/j.lwt.2017.12.017

16. Plagemann I, Krings U, Berger RG, Marostica MR. Volatile constituents of jabuticaba (Myrciaria jaboticaba (Vell.) O. Berg) fruits. J Essent Oil Res. 2012 Feb;24(1):45-51, doi: 10.1080/10412905.2012.645651

17. Balisteiro DM, Araujo RL de, Giacaglia LR, Genovese MI. Effect of clarified Brazilian native fruit juices on postprandial glycemia in healthy subjects. Food Res Int. 2017 Oct;100:196-203.

18. Hsu J-D, Wu C-C, Hung C-N, Wang C-J, Huang H-P. Myrciaria cauliflora extract improves diabetic nephropathy via suppression of oxidative stress and inflammation in streptozotocin-nicotinamide mice. $\mathrm{J}$ Food Drug Anal. 2016 Oct;24(4):730-7, doi: 10.1016/j.jfda.2016.03.009

19. Ahmed J, Shivhare US, Sandhu KS. Thermal Degradation Kinetics of Carotenoids and Visual Color of Papaya Puree. J Food Sci. 2002 Sep;67(7):2692-5, doi: 10.1111/j.1365-2621.2002.tb08800.x

20. Kara Ş, Erçelebi EA. Thermal degradation kinetics of anthocyanins and visual colour of Urmu mulberry (Morus nigra L.). J Food Eng. 2013 May;116(2):541-7, doi: 10.1016/j.jfoodeng.2012.12.030

21. Giusti MM, Wrolstad RE. Characterization and Measurement of Anthocyanins by UV-Visible Spectroscopy. Curr Protoc Food Anal Chem. 2001 Apr;00(1):F1.2.1-F1.2.13, doi: 10.1002/0471142913.faf0102s00

22. Benford D, Halldorsson T, Jeger MJ, Knutsen HK, More S, Naegeli H, et al. Guidance on Uncertainty Analysis in Scientific Assessments. EFSA J. 2018 Jan;16(1), doi: 10.2903/j.efsa.2018.5123

23. de Rosso VV, Mercadante AZ. The high ascorbic acid content is the main cause of the low stability of anthocyanin extracts from acerola. Food Chem. 2007 Jan;103(3):935-43, doi: 10.1016/j.foodchem.2006.09.047

24. de Rosso VV, Mercadante AZ. Evaluation of colour and stability of anthocyanins from tropical fruits in an isotonic soft drink system. Innov Food Sci Emerg Technol. 2007 Sep;8(3):347-52, doi: 10.1016/j.ifset.2007.03.008

25. Daravingas G, Cain RF. Thermal Degradation of Black Raspberry Anthocyanin Pigments in Model Systems. J Food Sci. 1968 Mar;33(2):138-42, doi: 10.1111/j.1365-2621.1968.tb01338.x 
26. Garcia-Viguera C, Zafrilla P, Romero F, Abellan P, Artes F, Tomas-Barberan FA. Color Stability of Strawberry Jam as Affected by Cultivar and Storage Temperature. J Food Sci. 1999 Mar;64(2):243-7, doi: 10.1111/j.1365-2621.1999.tb15874.x

27. Eyring H. The Activated Complex in Chemical Reactions. J Chem Phys. 1935 Feb;3(2):107-15, doi: 10.1063/1.1749604

28. Barsa CS, Normand MD, Peleg M. On Models of the Temperature Effect on the Rate of Chemical Reactions and Biological Processes in Foods. Food Eng Rev. 2012 Dec;4(4):191-202, doi: 10.1007/s12393-012-9056-X

29. Cisse M, Vaillant F, Acosta O, Dhuique-Mayer C, Dornier M. Thermal Degradation Kinetics of Anthocyanins from Blood Orange, Blackberry, and Roselle Using the Arrhenius, Eyring, and Ball Models. J Agric Food Chem. 2009 Jul;57(14):6285-91, doi: 10.1021/jf900836b

30. Huang L, Hwang A, Phillips J. Effect of Temperature on Microbial Growth Rate-Mathematical Analysis: The Arrhenius and Eyring-Polanyi Connections. J Food Sci. 2011 Oct;76(8):E553-60, doi: 10.1111/j.1750-3841.2011.02377.x

31. Karaaslan M, Yilmaz FM, Cesur Ö, Vardin H, Ikinci A, Dalgiç AC. Drying kinetics and thermal degradation of phenolic compounds and anthocyanins in pomegranate arils dried under vacuum conditions. Int J Food Sci Technol. 2014 Feb;49(2):595-605, doi: 10.1111/ijfs.12342

32. Patras A, Brunton NP, O’Donnell C, Tiwari BK. Effect of thermal processing on anthocyanin stability in foods; mechanisms and kinetics of degradation. Trends Food Sci Technol. 2010 Jan;21(1):3-11, doi: 10.1016/j.tifs.2009.07.004

33. Ju ZY, Howard LR. Effects of Solvent and Temperature on Pressurized Liquid Extraction of Anthocyanins and Total Phenolics from Dried Red Grape Skin. J Agric Food Chem. 2003 Aug;51(18):5207-13, doi: 10.1021/jf0302106

34. Nobre BP, Mendes RL, Queiroz EM, Pessoa FLP, Coelho JP, Palavra AF. Supercritical carbon dioxide extraction of pigments from Bixa orellana seeds (experiments and modeling). Brazilian J Chem Eng. 2006 Jun;23(2):251-8.

35. Alasalvar C, Al-Farsi M, Shahidi F. Compositional characteristics and antioxidant components of Cherry Laurel varieties and Pekmez. J Food Sci. 2005 Jan;70(1):S47-52, doi: 10.1111/j.13652621.2005.tb09064.x

36. Moldovan B, David L, Chişbora C, Cimpoiu C. Degradation kinetics of anthocyanins from european cranberrybush (Viburnum opulus L.) fruit extracts. Effects of temperature, pH and storage solvent. Molecules. 2012 Sep;17(10):11655-66, doi: 10.3390/molecules171011655

37. Kechinski CP, Guimarães PVR, Noreña CPZ, Tessaro IC, Marczak LDF. Degradation kinetics of anthocyanins in blueberry juice during thermal treatment. J Food Sci. 2010 Mar;75(2):C173-6, doi: 10.1111/j.1750-3841.2009.01479.x

38. Mercali GD, Jaeschke DP, Tessaro IC, Marczak LDF. Degradation kinetics of anthocyanins in acerola pulp: Comparison between ohmic and conventional heat treatment. Food Chem. 2013 Jan;136(2):853-7, doi: 10.1016/j.foodchem.2012.08.024

39. Martynenko A, Chen Y. Degradation kinetics of total anthocyanins and formation of polymeric color in blueberry hydrothermodynamic (HTD) processing. J Food Eng. 2016 Feb;171:44-51, doi: 10.1016/j.jfoodeng.2015.10.008 